\title{
Convergent sensing pathways mediate response to two extracellular competence factors in Bacillus subtilis
}

\author{
Jonathan M. Solomon, Roy Magnuson, Alok Srivastava, and Alan D. Grossman ${ }^{1}$ \\ Department of Biology, Massachusetts Institute of Technology, Cambridge, Massachusetts 02139 USA
}

Development of genetic competence in Bacillus subtilis is regulated by extracellular signaling molecules, including the ComX pheromone, a modified 9- or 10-amino-acid peptide. Here, we present characterization of a second extracellular competence stimulating factor (CSF). CSF appears to be, at least in part, a small peptide of between 520 and $\mathbf{7 2 0}$ daltons. Production of CSF requires several genes that are needed both for initiation of sporulation and development of competence $(\mathrm{spoOH}, \mathrm{spoOA}$, spoOB, and spoOF). Although both peptide factors regulate competence, two different sensing pathways mediate the response to the ComX pheromone and CSF. Analysis of double mutants indicated that ComX pheromone is on the same genetic pathway as the membrane-bound histidine protein kinase encoded by $\operatorname{comP}$ and that CSF is on the same genetic pathway as the oligopeptide permease encoded by spo0K. Furthermore, the cellular response to partly purified ComX pheromone requires the ComP histidine protein kinase, whereas the response to partly purified CSF requires the Spo0K oligopeptide permease. These two sensing pathways converge to activate transcription of comS (in the srfA operon), a key regulatory factor required for activation of additional competence genes. Both factors and their convergent sensing pathways are required for normal development of competence and might function to integrate different physiological signals.

[Key Words: B. subtilis; genetic competence; sporulation; signal transduction; cell-cell signaling]

Received November 17, 1994; revised version accepted February 2, 1995.

Cells communicate with each other to coordinate their activities. In bacteria, the secretion of and response to signaling molecules regulates many aspects of differentiation, development, pathogenesis, and symbiosis (Shapiro et al. 1993 and references therein). Characterizing the mechanisms by which bacterial cells produce, sense, and respond to extracellular signals is crucial to understanding these processes. The exchange of genetic material between bacteria is frequently regulated by cell-cell signaling. Transfer of conjugative plasmids in Enterococcus faecalis is induced by peptide pheromones (Clewell 1993). The development of genetic competence, the natural ability to take up DNA, is controlled by extracellular peptide factors in some species, including Streptococcus pneumoniae and Bacillus subtilis (Tomasz and Hotchkiss 1964; Tomasz and Mosser 1966; Joenje et al. 1972; Hui and Morrison 1991; Magnuson et al. 1994).

Development of competence in B. subtilis involves major changes in gene expression and metabolism. Under appropriate nutritional and cell density conditions a subpopulation of a culture of $B$. subtilis differentiates into a competent state (for review, see Dubnau 1991). Competent cells have a different buoyant density and are

\footnotetext{
${ }^{1}$ Corresponding author.
}

metabolically less active than noncompetent cells. During competence development, cells express specialized proteins that bind and take up DNA. Recombination is efficient between incoming DNA and homologous host sequences. The regulation of competence can be divided into two stages. The first stage leads to expression of the srfA operon. Gene products involved in producing and sensing extracellular factors all affect transcription of $\operatorname{srf} A$, and expressing $\operatorname{srf} A$ from a heterologous promoter bypasses the need for genes upstream in the pathway and leads to constitutive levels of competence (Hahn and Dubnau 1991; Nakano and Zuber 1991). Within the srfA operon is an open reading frame, coms ( $\mathrm{D}^{\prime}$ Souza et al. 1994; Hamoen et al. 1995), whose expression is required for the second stage of competence regulation, the activation of the ComK transcription factor (D'Souza et al. 1994; Kong and Dubnau 1994; Msadek et al. 1994; van Sinderen et al. 1994; Hamoen et al. 1995). ComK activates transcription of the genes encoding components of the competence machinery, including the com $G$ operon (Albano et al. 1987, 1989; Hahn et al. 1994; van Sinderen et al. 1994; van Sinderen and Venema 1994).

Expression of srf $A$ increases as cells grow to high density as a result of the accumulation of extracellular peptide factors in the culture medium (Magnuson et al. 1994). One of these extracellular factors, the ComX pher- 
omone, has been purified to homogeneity. It is a 9- to 10-amino-acid peptide with a modified tryptophan residue (Magnuson et al. 1994). The peptide portion of ComX pheromone is encoded by the last 10 codons of $\operatorname{com} X$. Production of the active pheromone also requires $\operatorname{com} Q$, the gene immediately upstream of $\operatorname{com} X$.

We describe the characterization and partial purification of a second extracellular competence factor that is distinct from the ComX pheromone. This competencestimulating factor (called CSF) is, at least in part, a small peptide and is required for normal expression of $\operatorname{srf} A$ and the development of competence. Experiments described below also demonstrate that the two extracellular competence factors act upon two different sensing pathways that converge to stimulate expression of $\operatorname{srf} A$ to activate the next stage of competence regulation. The two pathways are summarized schematically in Figure 1.

The histidine protein kinase encoded by $\operatorname{comP}$ (Weinrauch et al. 1990/ was found to be required for response

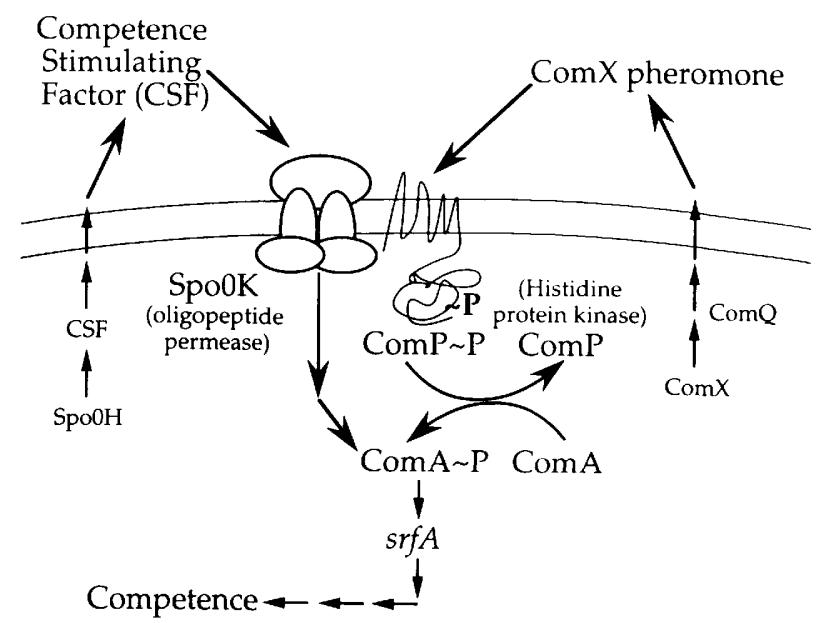

Figure 1. Model for the production of and response to the two extracellular competence factors. The cell membrane is shown with the two competence pheromones, ComX pheromone and CSF, outside the cell. ComX is the precursor for the peptide portion of ComX pheromone, and ComQ is required for production (presumably processing or modification) of ComX pheromone (Magnuson et al. 1994). Normal production of CSF requires the alternate $\sigma$ factor encoded by $s p o O H$. Other $s p o O$ genes affect expression of CSF by inactivating a negative regulator of CSF production, $a b r B$ (Table 1). Both competence factors stimulate expression of $\operatorname{srf} A$, which is part of a network of regulators that lead to competence development. The ComP histidine protein kinase, with eight putative membrane-spanning domains (Weinrauch et al. 1990), is required for detection of ComX pheromone but not for detection of CSF. Phosphate from ComP P is probably transferred to and activates the ComA transcription factor, which acts directly at the $s r f A$ promoter (Roggiani and Dubnau 1993). The SpoOK oligopeptide permease is essential for detection of CSF but not for detection of ComX pheromone. (SpoOK is not required for production of either CSF or ComX pheromonel. We hypothesize that SpoOK and CSF affect transcription of $\operatorname{srf} A$ by modulation of the levels of ComA $\sim \mathrm{P}$, by activating another kinase, by inhibiting a phosphatase, or by interacting directly with ComA. to ComX pheromone (Fig. 1). The ComP histidine protein kinase has eight putative membrane-spanning domains (Weinrauch et al. 1990) and is a member of the large family of two component regulatory systems that sense and transduce a variety of signals in prokaryotes and eukaryotes (Bourret et al. 1991; Chang et al. 1993; Ota and Varshavsky 1993; Alex and Simon 1994). These kinases autophosphorylate in response to a signal, often sensed by their amino-terminal domain, and the phosphate is transferred to the cognate response regulator, usually a transcription factor, which is activated by phosphorylation. The cognate response regulator for ComP is the $\operatorname{com} A$ gene product, a transcription factor that binds to the $\operatorname{srf} A$ promoter region (Roggiani and Dubnau 1993) and is required for transcription of srfA (Nakano and Zuber 1989; van Sinderen et al. 1990; Hahn and Dubnau 1991; Nakano and Zuber 1991; Nakano et al. 1991a,b).

The oligopeptide permease encoded by spoOK (Perego et al. 1991; Rudner et al. 1991) was found to be required for sensing CSF. SpoOK oligopeptide permease transports oligopeptides into $B$. subtilis and is a member of the ATP-binding cassette (ABC) family of transporters (Perego et al. 1991; Rudner et al. 1991) that link ATP hydrolysis to the import and export of a variety of compounds (Higgins 1992).

\section{Results}

The defect in expression of srfA caused by a null mutation in $\mathrm{spoOH}$ is rescued extracellularly

Expression of $\operatorname{srf} A$ is low at low cell densities, and when cells reach an optical density (at $600 \mathrm{~nm}$ ) of $0.2-0.3$ $\left(\sim 2 \times 10^{7}\right.$ to cells $\left./ \mathrm{ml}\right)$ extracellular factors accumulate to a critical level and expression of $\operatorname{srf} A$ increases (Fig. 2A; Magnuson et al. 1994). Full expression of $\operatorname{srf} A$ (also known as $c s h 293, c o m L$ ) requires the $s p o O H$ gene product (Jaacks et al. 1989; van Sinderen et al. 1990; Nakano et al. 1991a), a $\sigma$ factor $\left(\sigma^{\mathrm{H}}\right)$ of RNA polymerase that is required for the initiation of sporulation. Mutations in spoOH cause a defect in the development of competence (Sadaie and Kada 1983; Albano et al. 1987), at least in part because of a decrease in expression of $\operatorname{srf} A$ (Jaacks et al. 1989; Hahn and Dubnau 1991). The defect in expression of $\operatorname{srf} A$ in the $s p o O H$ mutant was most severe before the culture entered stationary phase (Fig. 2A). After entry into stationary phase, $\beta$-galactosidase specific activity from a srfA-lacZ fusion in the $s p o O H$ mutant reached $\sim 30 \%$ of that in wild-type cells (data not shown), as described previously (Nakano et al. 1988; Hahn and Dubnau 1991). The spoOH mutation also caused a defect in expression of com G (Fig. 2B; Albano et al. 1987), a late competence gene.

The defect in expression of $\operatorname{srf} A$ in the $s p o O H$ mutant was rescued by the addition of conditioned medium. Conditioned medium was made by growing $s p o O H^{+}$ cells, (lacking any lac $Z$ fusion) to high density, removing the cells by centrifugation, and filter sterilizing the medium (Materials and methods). When added to a $s p o O H$ 


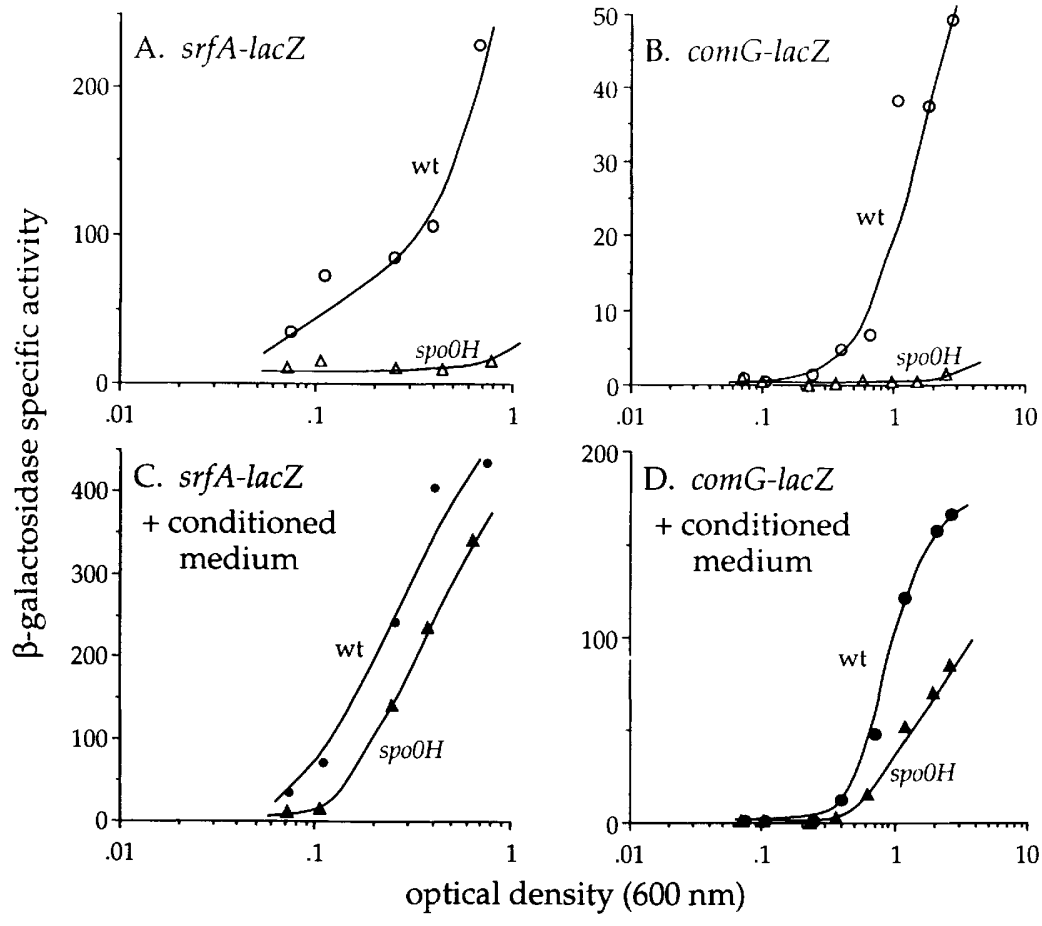

Figure 2. Expression of $s r f A-l a c Z$ and $c o m G-$ lac $Z$ in wild type and a spoOH mutant in the presence and absence of conditioned medium. Cells were grown in defined minimal medium for at least three doublings before the start of the experiment. When cells reached an optical density $(600$ $\mathrm{nm}$ ) of $\sim 0.1$, an equal volume of either fresh me$\operatorname{dium}(A, B)$ or conditioned medium from wildtype cells $|C, D|$ was added. Samples were then taken at the indicated densities for determination of $\beta$-galactosidase specific activity. $(A, C)$ Circles indicate JRL293 (srfA-lacZR1974 wildtype); triangles indicate JMS139 (srfA-lacZ 21974 spoOH::cat). $(B, D)$ Circles indicate AG1046 (comG-lacZ wild type); triangles indicate JMS128 (comG-lacZ spoOH::cat). Note that the scales on the $y$-axis are different in each panel. mutant, conditioned medium restored expression of $\operatorname{srfA}$ to a level similar to that in wild-type cells (Fig. 2C). The addition of conditioned medium to the $s p o O H$ mutant also substantially restored expression of comG-lacZ (Fig. 2D).

Extracellular rescue of the spoOH mutant was also demonstrated in cell-mixing experiments. $\mathrm{spoOH} \mathrm{mu-}$ tant cells containing the comG-lacZ fusion were grown in mixed culture with either wild-type or $\mathrm{spoOH}$ cells, without a $l a c Z$ fusion, at a ratio of $\sim 1: 1$. Expression of comG-lacZ in the spoOH mutant was restored to near wild-type levels when mixed with wild-type cells (data not shown).

The decreased transformation frequency of the $\mathrm{spoOH}$ mutant was partially rescued extracellularly. Addition of conditioned medium increased the transformation frequency of the $\mathrm{spoOH}$ mutant by 5- to 20 -fold. This rescue was never up to wild-type levels of transformation and was usually $\sim 10 \%$ of wild-type. Thus, the $\mathrm{spoOH}$ mutant can be fully rescued for expression of SrfA and partly rescued for expression of com $G$ and competence, by the addition of conditioned medium.

\section{Production of CSF is reduced in a spo0 $\mathrm{H}$ mutant}

Because expression of $\operatorname{srf} A$ is regulated by extracellular factors that accumulate in culture medium and the defect in expression of $s r f A$ caused by the spoOH mutation was rescued extracellularly, it seemed likely that the spoOH mutant (and possibly other spoO mutants) was defective in the production of an extracellular competence factor. While purifying the ComX pheromone from conditioned medium, we had noticed a second chro- matographically distinct factor that stimulates expression of srfA-lacZ two- to threefold (Magnuson et al. 1994). The spoOH mutant was defective in production of this second factor. We fractionated conditioned medium from $\mathrm{spoOH}$ and wild-type strains and tested the fractions for the ability to induce expression of srfA-lacZ. Conditioned medium was adjusted to $\mathrm{pH} 2$ and applied to a C-18 Sep-pak column. The column was washed and step-eluted with increasing concentrations of acetonitrile, and fractions were dried in a Speedvac concentrator and resuspended in minimal medium (Materials and methods). The ComX pheromone elutes at $\sim 50 \%-60 \%$ acetonitrile (Magnuson et al. 1994). Fractions from the $10 \%$ acetonitrile eluate contained a second activity that also stimulated expression of $\operatorname{srf} A-\mathrm{lacZ}$ in cells at low density (Magnuson et al. 1994). Conditioned medium from the $s p o O H$ mutant had near normal levels of the ComX pheromone but had a reduced amount of the second factor (CSF), relative to conditioned medium from wild-type cells (Table 1). It appears therefore, that even a partial defect in the production of CSF, such as is observed in a spoOH mutant, is sufficient to cause a defect or delay in expression of srfA and the development of competence.

In addition to $s p o O H$, several other early sporulation genes were found to be required for normal production of CSF. spoOA encodes a transcription factor, the activity of which is regulated by phosphorylation, and the spoOF and $\triangle P O O B$ gene products are required to transfer phosphate from histidine protein kinases to Spo0A (Burbulys et al. 1991). One function of Spo0A $\sim \mathrm{P}$ is to repress transcription of $a b r B$ (Perego et al. 1988; Strauch et al. 1990), the product of which is a repressor of many functions 
Table 1. Production of CSF and the ComX pheromone in different mutants

\begin{tabular}{llcc}
\hline & & \multicolumn{2}{c}{ Percent production $^{a}$} \\
\cline { 3 - 4 } Strain & $\begin{array}{l}\text { Relevant } \\
\text { genotype }\end{array}$ & CSF & $\begin{array}{c}\text { ComX } \\
\text { pheromone }\end{array}$ \\
\hline JH642 & wild type & 100 & 100 \\
AG665 & spo0H::cat & 9.5 & 68 \\
AG503 & $\Delta$ spo0A475::cat & 3.2 & 129 \\
AG141 (JH648) & spo0B136 & 19 & 110 \\
AG144 (JH649) & spo0F221 & 23 & 110 \\
AG132 & spo0A204 abrB703 & 124 & 167 \\
\hline
\end{tabular}

${ }^{a}$ The amount of CSF and ComX pheromone per milliliter of conditioned medium was determined for each strain indicated. Data are normalized to the amount of CSF and ComX pheromone determined from wild-type conditioned medium prepared and treated similarly to a given mutant. For the experiments shown, the amount of CSF from conditioned medium from wild-type cells ranged from 1170 to $1460 \mathrm{U} / \mathrm{ml}$. The amount of ComX pheromone in conditioned medium from wild-type cells ranged from 72 to $210 \mathrm{U} / \mathrm{ml}$. Some of the variability in the measurements of ComX pheromone probably results from its tendency to stick to glass surfaces (Magnuson et al. 1994). Similar results were obtained in multiple experiments from several different preparations of conditioned medium.

that are expressed during the transition from growth to stationary phase (Strauch and Hoch 1993), including competence development (Albano et al. 1987).

$s p o 0 A$, spoOB, and $s p o 0 F$ were found to be required for normal production of CSF (Table 1). spoOA mutants are defective in expression of srfA (Nakano et al. 1988; Hahn and Dubnau 1991) and the development of competence (Sadaie and Kada 1983; Albano et al. 1987) as well as sporulation (Hoch 1993). Mutations in spoOF and spoOB caused a defect in expression of srfA-lacZ and comGlacZ (data not shown), and transformation frequencies were $\sim 0.2 \%-1 \%$ of wild-type in both minimal and complex (SpII) competence medium. The defect in CSF production caused by a null mutation in $s p o O A$ was relieved by a null mutation in $a b r B$ (Table 1), indicating that production of CSF is controlled by $\mathrm{AbrB}$, a regulator of stationary-phase gene expression (Strauch and Hoch 1993).

Although $s p \circ 0 A$, spoOF, and $s p o O B$ are needed for production of CSF, they also appear to be required for cells to respond to CSF. The defect in srfA-lacZ and comG$1 a c Z$ expression caused by mutations in $s p o 0 A$, spoOB, and $S p O O F$ was not fully relieved by the addition of conditioned medium (data not shown), in contrast to results with $\mathrm{spoOH}$ (above). These findings are consistent with the requirement for $\operatorname{spoOA}$ and $a b r B$ in the expression of the late competence transcription factor encoded by $\operatorname{comK}$ (Hahn et al. 1994; van Sinderen and Venema 1994).

\section{CSF is distinct from ComX pheromone and appears to be a small peptide}

Preliminary characterization of CSF from conditioned medium indicated that it is at least in part a small peptide. CSF activity passed through filters with a nominal molecular weight cutoff of 10,000 daltons and was sensitive to treatment with trypsin or pronase (data not shown). CSF was partially purified from conditioned medium from $s p o O H^{+}$cells (Materials and methods). Briefly, conditioned medium was adjusted to $\mathrm{pH} 2$ by addition of trifluoroacetic acid (TFA) and passed over a Sep-pak C-18 cartridge. CSF was eluted with $10 \%$ acetonitrile, dried in a Speedvac concentrator and resuspended. Material was then applied to a sulfopropyl Sephadex (SP) column, and CSF activity eluted at $\sim 60 \mathrm{~mm}$ $\mathrm{NaCl}$. Active fractions were pooled and rechromatographed over a C-18 Sep-pak cartridge and then applied to an HPLC C-18 column. The column was eluted with a gradient of acetonitrile from 0 to $10 \%$, and active fractions were pooled and rerun under similar conditions. Active fractions were again pooled and rerun, this time eluting with a very shallow gradient (Fig. 3).

To date, the most pure preparations of CSF have a complex elution profile from reverse-phase chromatography (Fig. 3) and contain multiple components as indicated by mass spectrometry. Mass spectrometry analysis of the active fractions from this purification (Fig. 3) revealed seven components ranging in mass from $\sim 520$ to 720 daltons. If CSF is an unmodified peptide and its mass is identical or similar to any of the components detected, then CSF is probably a peptide of $4-7$ amino acids.

spoOK and comP appear to be on different, but convergent, response pathways

To determine whether there is more than one pathway activating expression of $s r f A$ in response to the two extracellular competence factors, a variety of double mutant strains were constructed and analyzed. If two genes are on the same pathway, then a double (null) mutant should have the same phenotype that is observed in the strongest single mutant. If two genes are on different

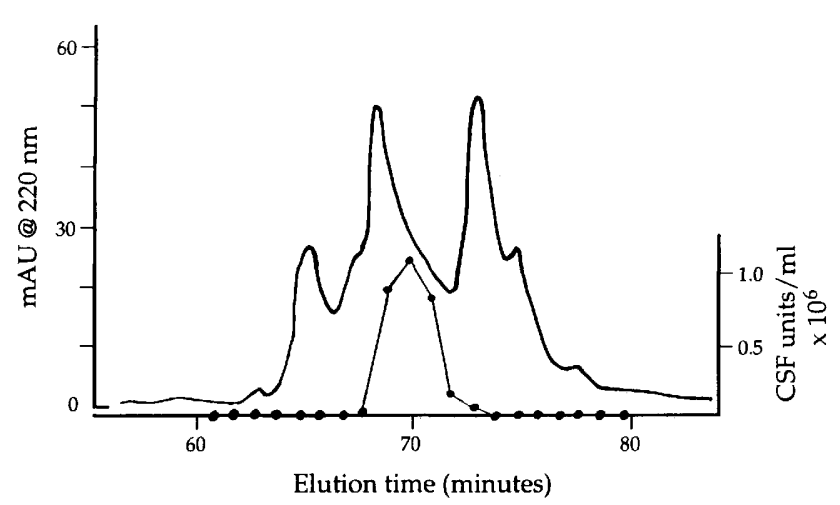

Figure 3. HPLC reverse-phase chromatography of CSF. CSF was purified from conditioned medium and assayed as described in Materials and methods. A C-18 reverse phase column was eluted with a gradient of acetonitrile $(0.04 \% / \mathrm{min})$, from $0 \%$ to $10 \%$ in $0.1 \%$ TFA. Milliabsorbance at $220 \mathrm{~nm}$ is indicated at left; CSF activity is indicated at right (O). 
pathways that affect the same process, then the double mutant should have a more severe phenotype than either of the single mutants.

Expression of $\operatorname{srf} A$ was greatly reduced in $\operatorname{com} P$ (histidine protein kinase) and $s p o 0 K$ (oligopeptide permease) null mutants (Fig. 4A), as seen previously (Hahn and Dubnau 1991; Magnuson et al. 1994). At an optical density of $\sim 2$ (at $600 \mathrm{~nm}$ ), accumulation of $\beta$-galactosidase specific activity from $\operatorname{srf} A-1 a c Z$ in the comP mutant and the spoOK mutant was $\sim 5 \%$ and $\sim 2 \%$, respectively, of that in the wild type (Fig. 4). Despite the large effects (Fig. 4A), there was still detectable expression of $s r f A$ in these mutants (Fig. 4B). Expression of $\operatorname{srf} A$ was more readily detectable in these experiments than in previous work (Hahn and Dubnau 1991; Magnuson et al. 1994) because of the use of a more active $s r f A-l a c Z$ fusion (Materials and methods).
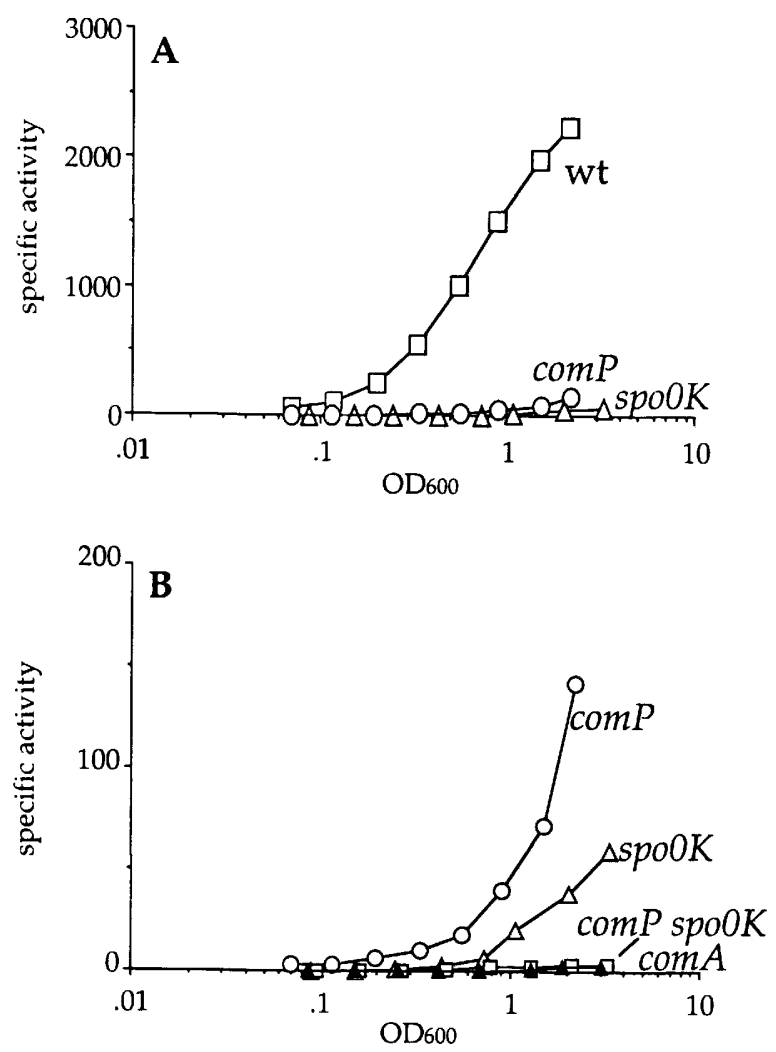

Figure 4. $\operatorname{com} P$ and $s p o O K$ are on different pathways for the activation of $s r f A$ transcription. Isogenic strains containing the srf $A-l a c Z \Omega 374$ fusion were grown in defined minimal medium for at least three generations before the start of the experiment. Samples were taken for determination of $\beta$-galactosidase specific activity at the indicated cell densities. $(A)$ Expression of $\operatorname{srf} A$ is reduced in $\operatorname{comP}$ and spoOK mutants. ( $\square$ ) JMS374

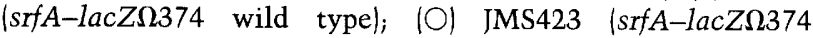
comP::cat); $(\triangle)$ JMS384 (srfA-lacZ $\Omega 374 \Delta$ spoOK::erm). (B) srfA expression in the comP spoOK double mutant is lower than in spoOK or comP single mutants. (O) JMS423 (srfA-lacZ

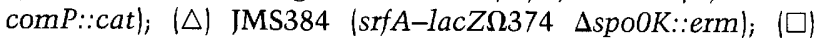
IMS425 (srfA-lacZ $\Omega 374$ comP::cat $\triangle$ spoOK::erm) ${ }_{i}$ (A) ROM306 (srfA-lacZ $\Omega 374$ comA::cat).
Expression of $\operatorname{srf} A$ in the $\operatorname{com} P$ spoOK double mutant was significantly lower than that in either single mutant, $\sim 0.1 \%$ of wild type and barely above background, and was similar to that in a comA null mutant (Fig. 4B). These results indicate that the SpoOK oligopeptide permease and the ComP histidine protein kinase are on different pathways for activation of $\operatorname{srf} A$ transcription. The residual expression of $s r f A$ in cells lacking the $S p o 0 \mathrm{~K}$ oligopeptide permease depends on the presence of ComP, and the residual expression of $\operatorname{srf} A$ in cells lacking the ComP histidine protein kinase depends on the presence of SpoOK. Normal expression of $\operatorname{srf} A$ requires both ComP and $\mathrm{SpoOK}$, and eliminating both of these components is similar to eliminating the ComA transcription factor that directly regulates expression of $\operatorname{srf} A$.

We also used double mutant analysis to determine which of the extracellular competence factors, ComX pheromone or CSF, is on the same pathway as the ComP histidine protein kinase and/or the SpoOK oligopeptide permease. Cells lacking ComX pheromone (because of a nonpolar mutation in comQ) and ComP (a com $Q \operatorname{com} P$ double mutant) were no more impaired in $\operatorname{srf} A$ transcription than cells lacking only ComP (Fig. 5A), indicating that the ComX pheromone is on the same pathway as the ComP histidine protein kinase. In contrast, expression of $s r f A$ was lower in the $s p o O H$ comP double mutant than in either single mutant (Fig. 5A,C). The spoOH mutation causes reduced production of CSF (above), and this combined effect on $\operatorname{srf} A$ expression suggests that CSF and ComP are on different pathways for activation of srf $A$ transcription (Fig. 1).

The SpoOK oligopeptide permease and CSF were found to be on the same pathway. Cells lacking SpoOK and producing reduced amounts of CSF la $s p o O K$ spoOH double mutant) were no more impaired for $\operatorname{srf} A$ expression than cells lacking only SpoOK (Fig. 5B). In contrast, when production of the ComX pheromone was eliminated in cells lacking SpoOK (a comQ spoOK double mutant), expression of $\operatorname{srf} A$ was lower than in either single mutant (Fig. 5B). These results indicate that SpoOK and ComX pheromone are on different pathways (Fig. 1).

We also measured expression of $\operatorname{srf} A$ in cells that are fully capable of responding to both factors but that do not produce ComX pheromone and produce reduced amounts of CSF, a comQ spoOH double mutant. As expected, this double mutant was more defective in expression of $\operatorname{srf} A$ than either single mutant (Fig. 5C).

The genetic evidence clearly shows that two pathways stimulate expression of $\operatorname{srf} A$ : ComX pheromone and the ComP histidine protein kinase are on one pathway, and $\mathrm{CSF}$ and SpoOK are on the other pathway. Double mutants affecting both pathways had a combined effect on srf $A$ expression, and double mutants affecting only a single pathway had the same effect as the single mutants.

ComP is required for response to Com $X$ pheromone and $S p o O K$ is required for response to CSF

We determined directly whether the SpoOK oligopeptide permease or the ComP histidine protein kinase is needed 

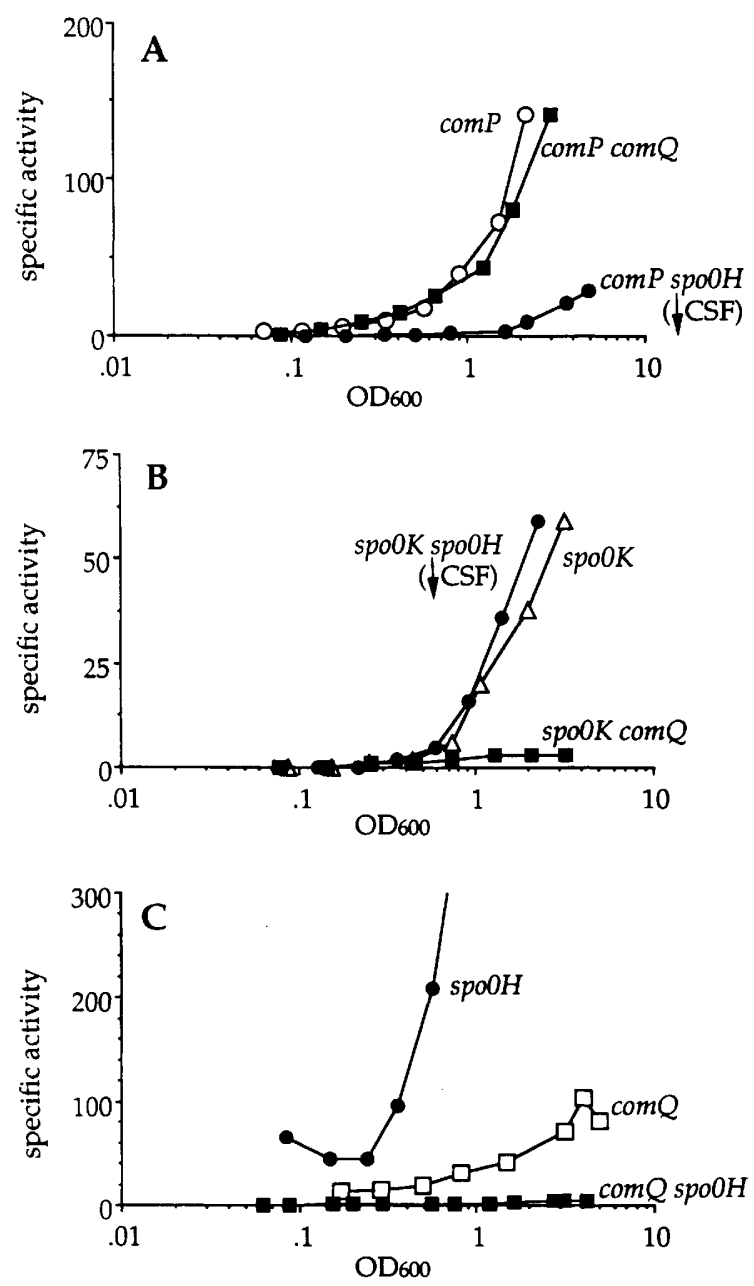

Figure 5. Effects of double mutant combinations on expression of $s r f A$. Isogenic strains containing the $\operatorname{srf} A-l a c Z \Omega 374$ fusion were grown as described in Fig. $4 .(A) \operatorname{com} P$ is on the same genetic pathway as com $Q$ but on a different pathway than spoOH. (O) JMS423 (comP::cat); (口) ROM294 (comP::cat comQ::spc); (O) JMS478 (spoOH::cat comP::spc). (B) spoOK is on the same genetic pathway as $\mathrm{spoOH}$ but on a different pathway than comQ. $(\triangle)$ IMS384 (spoOK:::erm); (O) JMS433 (spoOK::erm spoOH::cat); (口) JMS426 (spoOK::erm comQ::spc). (C) comQ and $s p o O H$ are on different genetic pathways for the activation of srfA expression. (O) JMS441 (spoOH::cat); (ㅁ) JMS424 (comQ::spc); (口) JMS477 (comQ::spc spoOH::cat).

for response to either ComX pheromone or CSF. We measured induction of $s r f-l a c Z$ in cells at low density in response to addition of either partly purified ComX pheromone or partly purified CSF. ComP was required for sensing of ComX pheromone. Cells lacking the ComP histidine protein kinase were unable to induce transcription of $\operatorname{srf} A-\mathrm{lac} Z$ in response to the addition of partly purified ComX pheromone (Fig. 6A). In contrast, cells lacking the SpoOK oligopeptide permease responded well to ComX pheromone, suggesting that SpoOK is not essential for detection of this factor (Fig. 6A). Spo0K, however, was needed for the sensing of CSF. Cells lacking the SpoOK oligopeptide permease were unable to in- duce transcription of $s r f A-l a c Z$ in response to the addition of partly purified CSF (Fig. 6B). Cells lacking ComP had the normal two- to threefold response to CSF (Fig. $6 \mathrm{~B}$ ), indicating that ComP was not essential for detection of CSF.

\section{Effect of double mutants on transformation efficiency}

Analysis of the competence defects in double mutants indicates that a threshold level of $\operatorname{srf} A$ expression may be needed to activate the next step in competence development. Double mutations that had combined effects on expression of srfA did not have combined effects on competence development, determined by measuring transformation frequency. comP (JRL177), spooK (JRL358), and srfA (ROM77) single mutants all had transformation efficiencies $\sim 1-2 \%$ of that of otherwise isogenic wildtype, as reported previously (Jaacks et al. 1989; van Sinderen et al. 1990; Weinrauch et al. 1990; Rudner et al. 1991; van Sinderen and Venema 1994). We found that a spoOK comP double mutant (JMS425) also had a transformation frequency $\sim 1-2 \%$ of wild-type, indistinguishable from that of either single mutant. In essence, mutations in either branch of the response pathway that cause reduced expression of $\operatorname{srf} A$ cause a defect in competence development similar to that caused by no expression of srfA (a null mutation in $\operatorname{srfA}$, or $\operatorname{com} A$ ). These results are most consistent with the notion that a critical threshold level of expression of $\operatorname{srf} A$ must be
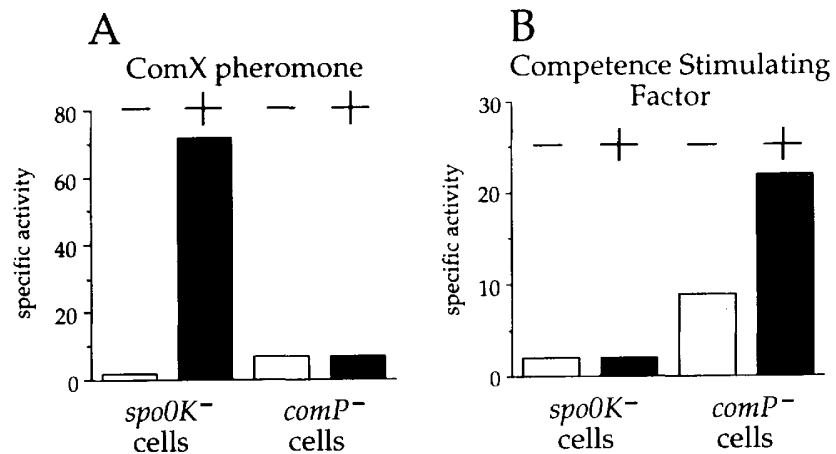

Figure 6. Response of $s p o O K$ and comP mutant cells to partly purified ComX pheromone and partly purified CSF. Strains JMS384 (srfA-lacZN374 $\Delta$ spoOK::erm) and JMS423 (srfAlacZ $\Omega 374$ comP::cat) were grown in defined minimal medium allowing at least three doublings before the start of the experiment. At an optical density $(600 \mathrm{~nm})$ of $\sim 0.1$, cells were diluted $1: 1$ into fresh medium, or fresh medium plus partly purified ComX pheromone or CSF. All samples contained $50 \mu \mathrm{g} / \mathrm{ml}$ of bovine serum albumin to prevent the factors from adhering to the glass. The samples were incubated at $37^{\circ} \mathrm{C}$ in flasks in shaking water baths. Aliquots were taken for determination of $\beta$-galactosidase specific activity 45,90 , and $135 \mathrm{~min}$ after dilution. (A) Response to ComX pheromone requires ComP but not SpoOK. Data from the $45-$ min time point is shown. $1-$ and +1 The absence and presence of ComX pheromone. $(B)$ Response to CSF requires Spo0K but not ComP. Data from the 90-min time point is shown. ( - and +1 The absence and presence of CSF. 
reached to activate the next step in competence development.

In addition, the residual expression of $\operatorname{sr} A$ in the $\operatorname{com} P$ and spoOK mutants probably does not represent a subpopulation of cells that are fully induced for expression of $s r f A$. If a small fraction of the single mutants had full levels of expression of $\operatorname{srf} A$, then it would be expected that some of the fully expressing cells would go on to develop competence. In the double mutant (comP spoOK) there is less expression of $s r f A$ than in either single mutant, and if this represented a further reduction in the size of the subpopulation that was expressing $\operatorname{srfA}$, it should also have caused a further reduction in the transformation frequency.

\section{Discussion}

This work demonstrates that two different extracellular signaling factors and two different response pathways, one for each of the extracellular factors, are necessary for the initiation of competence development in $B$. subtilis (Fig. 1). CSF is biochemically distinct from ComX pheromone, and different genes are required for production of each of these factors. Production of ComX pheromone (but not CSF) absolutely depends on $\operatorname{com} X$ and $\operatorname{com} Q$, the gene immediately upstream of $\operatorname{com} X$ (Magnuson et al. 1994). Production of CSF (but not ComX pheromone) is reduced significantly in $s p o O H, s p o O A$, $s p o O B$, and spoOF mutants.

The oligopeptide permease encoded by spoOK is required for response to CSF, and the membrane-bound histidine protein kinase encoded by $\operatorname{com} P$ is required for response to the ComX pheromone (Fig. 1). Double mutant analysis indicated that CSF is on the same signaling pathway as Spo0K oligopeptide permease, and the ComX pheromone is on the same signaling pathway as ComP histidine protein kinase. Both pathways converge to activate expression of $\operatorname{srf} A$, and we suspect that they converge to regulate production and accumulation of ComA $\sim \mathrm{P}$. Consistent with this notion is the finding that overexpression of $\operatorname{com} A$ on a multicopy plasmid bypasses the need for $\operatorname{com} P$ and $s p o O K$ in competence development (Weinrauch et al. 1990; Dubnau 1993), indicating that ComA is downstream of both the ComP histidine protein kinase and the $\mathrm{SpoOK}$ oligopeptide permease.

ComX pheromone probably interacts directly with ComP histidine protein kinase to stimulate autophosphorylation activity of ComP. ComP has eight putative membrane-spanning domains, and it is likely that several regions of the protein are exposed on the cell surface (Weinrauch et al. 1990). Many other members of the family of histidine protein kinases are membrane proteins involved in signal transduction (Bourret et al. 1991; Parkinson and Kofoid 1992).

SpoOK oligopeptide permease probably transports CSF into the cell where CSF then interacts with a downstream target. CSF is in the size range of peptides transported by oligopeptide permeases (Tynkkynen et al. 1993), and a functional transporter seems to be required for the response. In addition, mutations that activate a cryptic oligopeptide permease bypass the need for SpoOK in competence (Koide and Hoch 1994) (J.M. Solomon, N. Gunther, S. Shyn, and A.D. Grossman, unpubl.), consistent with the notion that CSF is transported into the cell. SpoOK oligopeptide permease belongs to a large family of transporters that couple ATP hydrolysis to the import or export of specific compounds. The cystic fibrosis transmembrane regulator (CFTR), multidrug resistance protein (MDR), and many bacterial importers, including those for maltose, phosphate, and histidine, are members of this family (Higgins 1992). SpoOK is able to transport a variety of peptides into $B$. subtilis, and these peptides can be used as a nutrient source. However, such peptides do not stimulate competence development.

Another possibility that cannot yet be ruled out is that Spo0K functions as a receptor, and in the presence of CSF, is able to send a transmembrane signal to stimulate srfA expression. The Pst $\mathrm{ABC}$ transporter imports phosphate ions into Escherichia coli and also functions as a receptor to regulate the activity of the PhoR/PhoB two component regulatory system (Cox et al. 1988; Wanner 1993). In either model, transporter or receptor, we suspect that SpoOK and CSF act to stimulate accumulation of ComA P, perhaps by stimulating the activity of a kinase, inhibiting the activity of a phosphatase, or interacting with ComA directly.

It seems that the sensing of extracellular signaling molecules by components of $\mathrm{ABC}$ transporters might be widespread. $\mathrm{ABC}$ transporters are involved in the response to opines in Agrobacterium tumefaciens (Valdivia et al. 1991; Zanker et al. 1992). Some of the proteins required for the response to mating pheromones in $E$. faecalis are similar to the oligopeptide-binding proteins OppA and SpoOKA (Clewell 1993; Ruhfel et al. 1993; Tanimoto et al. 1993). In addition, oligopeptidebinding proteins are involved in the response to extracellular competence factors in $S$. pneumoniae (Pearce et al. 1994).

While pathways with multiple intercellular signals occur frequently in higher organisms (Cornell and Kimelman 1994), it is not clear why the development of genetic competence in $B$. subtilis requires two extracellular signals. One possibility is that two signals contribute to the species specificity of competence and DNA uptake. In contrast to some naturally competent organisms (e.g., Haemophilus influenzae and Neisseria gonnorhoea), which prefer to take up DNA containing a species-specific sequence (Smith and Danner 1981; Stewart 1989|, B. subtilis will bind and take up DNA of any sequence. Two signals could help to ensure that competence is induced only in the presence of other $B$. subtilis cells and not simply in the presence of a species that might produce one homologous signal.

It is also possible that the two signals each provide different information to the cells, perhaps indicating the density of the culture as well as some aspect of the nutritional state of the cells. For example, production of one or the other of the factors might be stimulated by glucose, which stimulates competence, or inhibited by 
glutamine, which inhibits competence. In this way, expression of $s r f A$ could serve to integrate two different signals that affect competence development. Signal integration during competence development also seems to occur at the step of activation of the ComK transcription factor, which depends on $\operatorname{srfA}(\mathrm{comS})$ and several other genes (Hahn et al. 1994; Kong and Dubnau 1994; Msadek et al. 1994; van Sinderen and Venema 1994; van Sinderen et al. 1994). Signal integration affecting the activity of a single transcription factor also occurs during the initiation of sporulation, the other developmental process associated with $B$. subtilis. Multiple diverse signals regulate the initiation of sporulation by affecting the phosphorylation of the transcription factor encoded by $s p O 0 \mathrm{~A}$ (Burbulys et al. 1991; Ireton and Grossman 1992, 1994; Ireton et al. 1993, 1994).

Competence is not the only developmental process in $B$. subtilis that is regulated by extracellular peptide factors. The initiation of sporulation is also regulated, in part, by cell crowding or high cell density. Cultures at low cell density do not sporulate efficiently, whereas similarly treated cultures at high density sporulate efficiently (Vasantha and Freese 1979; Grossman and Losick 1988; Waldburger et al. 1993). The decreased sporulation frequency of cells at low density is partly rescued by the addition of conditioned medium made from cells grown to high density (Grossman and Losick 1988; Waldburger et al. 1993). The conditioned medium appears to contain peptide factors that accumulate as cells grow to high density. The production of at least one extracellular sporulation factor is regulated by $s p o 0 A$, spoOB, spoOF, and $a b r B$ (Grossman and Losick 1988), similar to production of CSF.

It is tempting to speculate that CSF might be involved in the initiation of sporulation as well as the initiation of competence development. However, we have not found conditions in which partly purified CSF stimulates cells at low density to sporulate. It is possible that CSF is not involved in sporulation and that another density factor with some properties similar to CSF is required for efficient sporulation. Alternatively, if CSF is involved in the initiation of sporulation, we might not have found the proper conditions in which to measure its activity. The ComX pheromone plays a role in sporulation, at least under some conditions (Magnuson et al. 1994). However, it is not responsible for the entire effect of cell density on sporulation, and we have not found conditions in which CSF and ComX pheromone together have significantly greater effects on sporulation than ComX pheromone alone. Currently, we favor the hypothesis that there is probably a third extracellular factor, distinct from CSF and the ComX pheromone, that is involved in sporulation.

\section{Materials and methods}

\section{Strains}

Strains used are listed in Table 2. All are derived from B. subtilis strain JH642 and contain the trpC2 and pheA1 mutations. Mu- tant alleles used include comP::cat (Weinrauch et al. 1990), comQ::spc (Magnuson et al. 1994), comA::cat (D. Dubnau, Public Health Research Institute, NY), spoOH::cat (Jaacks et al. 1989), $\Delta$ spo0K358::erm (LeDeaux and Grossman 1995), and $\Delta$ spo0A475::cat (Grossman et al. 1992). The comG-lacZ fusion is a transcriptional fusion located at $a m y E$ (Magnuson et al. 1994).

\section{srfA-lacZ fusions}

Two different srfA-lacZ fusions were used. The srfAlacZ $\Omega 1974$ fusion is a translational fusion located in single copy at the $a m y E$ locus and was provided by J. Hahn and D. Dubnau (Hahn et al. 1994). It was used in most of the experiments involving the purification of CSF and had been used previously in the characterization of the ComX pheromone (Magnuson et al. 1994).

In addition, we constructed a new $s r f A-l a c Z$ transcriptional fusion at the $a m y E$ locus, amyE::(srfA-lacZ $\Omega 374$ neo). The srf $A$ promoter fragment, from -291 to +140 nucleotides relative to the srf $A$ transcription start site, with flanking EcoRI and BamHI restriction sites, was first isolated by PCR amplification of chromosomal DNA and cloned into the vector pGEM-cat. (Youngman et al. 1989|. DNA sequence was determined to verify that there were no changes compared with the published sequence of the $\operatorname{sif} A$ promoter region (Nakano et al. 1991b). The promoter fragment was then cloned into the lacZ fusion vector pKS2 (Magnuson et al. 1994) to generate pJS34, and the fusion was recombined into the chromosome by single crossover, selecting for neomycin resistance. $\beta$-Galactosidase specific activity from this transcriptional fusion is three- to fourfold higher than specific activity from the $\operatorname{srf} A-l a c Z$ translational fusion described previously (Hahn et al. 1994; Magnuson et al. 1994). Expression of this fusion was similar to that of fusions described previously (Nakano et al. 1988; Jaacks et al. 1989; van Sinderen et al. 1990; Hahn and Dubnau 1991; Nakano and Zuber 1991; Hahn et al. 1994; Magnuson et al. 1994) in that it was dependent on the same regulatory genes and was controlled similarly by cell density and nutritional conditions (data not shown).

\section{Media}

Defined minimal medium was used for most experiments and contained S7 salts (Vasantha and Freese 1980) except that MOPS buffer was used at 50 rather than $100 \mathrm{mM}$ (Jaacks et al. 1989). Medium contained glucose $(1 \%)$ and glutamate $(0.1 \%)$ and required amino acids ( 40 or $50 \mu \mathrm{g} / \mathrm{ml}$ ) as needed. SpII competence medium (Dubnau and Davidoff-Abelson 1971) was used in some experiments, except that $\mathrm{CaCl}_{2}$ was left out (Albano et al. 1987). The important difference between SpII medium and the defined minimal medium is the presence of yeast extract and casamino acids in the SpII medium. These components cause competence to develop after the end of exponential growth (Dubnau et al. 1991).

\section{$\beta$-Galactosidase assays}

$\beta$-Galactosidase specific activity was measured essentially as described (Miller 1972; Jaacks et al. 1989; Magnuson et al. 1994) and is presented as $\left(\Delta A_{420} / \mathrm{min}\right.$ per milliliter of culture per $\left.\mathrm{OD}_{600}\right) \times 1000$.

\section{Competence assays}

Cells were grown in defined minimal medium (or SpII), and the transformation frequency was determined by mixing cells with 
Table 2. Strains used

\begin{tabular}{|c|c|}
\hline Strain & Genotype or description \\
\hline JH642 (AG174) & $\operatorname{trp} C 2$ pheA1 \\
\hline AG132 & spo0A204 abrB703 (Grossman and Losick 1988) \\
\hline AG141 (JH648) & spo0B136 (Piggot and Coote 1976) \\
\hline AG144 (JH649) & spo0F221 (Piggot and Coote 1976) \\
\hline AG503 & $\Delta$ spo0A475::cat (Grossman et al. 1992) \\
\hline AG665 & spoOH::cat (Jaacks et al. 1989) \\
\hline AG1046 (JMS107) & amyE::(comG-lacZ neo) (Magnuson et al. 1994; Siranosian and Grossman 1994) \\
\hline JMS128 & amyE::(comG-lacZ neo) spoOH::cat \\
\hline JMS139 & amyE::(srfA-lacZ $\Omega 1974$ cat::spc) spoOH::cat \\
\hline JMS374 & amyE::(srfA-lacZ $\Omega 374$ neo) fusion 374 \\
\hline JMS384 & $\Delta$ spoOK::erm amyE::(srfA-lacZ $\Omega 374$ neo $)$ \\
\hline JMS423 & comP::cat amyE::(srfA-lacZ $\Omega 374$ neo) \\
\hline JMS424 & comQ::spc amyE::(srfA-lacZ $\Omega 374$ neo) \\
\hline JMS425 & $\Delta$ spoOK::erm comP::cat amyE::(srfA-lacZ $\Omega 374$ neo) \\
\hline JMS426 & comQ::spc $\Delta$ spo0K::erm amyE::(srfA-lacZ $\Omega 374$ neo) \\
\hline IMS433 & spoOH::cat $\Delta$ spoOK::erm amyE::(srfA-lacZ $\Omega 374$ neo) \\
\hline JMS441 & spoOH::cat amyE::(srfA-IacZ $\Omega 374$ neo) \\
\hline JMS477 & spoOH::cat comQ::spc amyE::(srfA-lacZ $\Omega 374$ neo) \\
\hline JMS478 & spoOH::cat comP::spc amyE::(srfA-lacZ $\Omega 374$ neo) \\
\hline JRL177 & comP::cat \\
\hline JRL293 (JMS108) & amyE::(srfA-lacZ $\Omega 1974$ cat $)$ \\
\hline JRL358 (JMS122) & $\Delta$ spo0K358::erm (LeDeaux and Grossman 1995) \\
\hline ROM77 (JMS117) & srfA::pRO106 (cat) plasmid pRO106 integrated, disrupting srfA \\
\hline ROM294 & $\operatorname{comP}::$ cat comQ::spc amyE::(srfA-lacZ $\Omega 374$ neo) \\
\hline ROM297 & $\operatorname{com} Q: \because s p c$ \\
\hline ROM302 & comQ::spc spoOH::cat \\
\hline ROM306 & $\operatorname{com} A::$ cat amyE::(srfA-lacZ $\Omega 374$ neo $)$ \\
\hline
\end{tabular}

chromosomal DNA $(\sim 1 \mu \mathrm{g} / \mathrm{ml})$ containing a selectable marker (e.g., spc, spectinomycin resistance) for 20 or $40 \mathrm{~min}$ (depending on the experiment at $37^{\circ} \mathrm{C}$ and plating on selective plates. Transformation frequency is the total number of transformants per viable cell. Typical frequencies for our wild-type strains (JH642 and derivatives) ranged from $\sim 5 \times 10^{-5}$ to $8 \times 10^{-4}$ transformants per viable cell.

\section{Conditioned medium and separation of CSF from ComX pheromone}

Conditioned medium was prepared by growing cultures in S7 minimal medium with glucose and glutamate, essentially as described (Grossman and Losick 1988; Magnuson et al. 1994) to an optical density of 2.5-3.5 at $600 \mathrm{~nm}$. Cells were removed by centrifugation, and supernatant medium was sterilized by filtration. CSF and the ComX pheromone were partially purified and separated from each other on a Sep-pak C-18 cartridge (Waters). Approximately $10-20 \mathrm{ml}$ of conditioned medium was adjusted to $\mathrm{pH} 2$ with TFA and applied to a 0.3-gram Sep-pak cartridge. CSF was eluted in $10 \%$ acetonitrile $(0.1 \%$ TFA), whereas the ComX pheromone was eluted in $60 \%$ acetonitrile $10.1 \%$ TFA $)$. Before elution of the ComX pheromone, the column was washed with $20 \%$ and $30 \%$ acetonitrile. Samples were typically stored frozen at $-20^{\circ} \mathrm{C}$. Before use, samples were thawed at room temperature and dried down completely in a Speedvac concentrator, resuspended in fresh minimal medium for physiological assays, and stored at $-20^{\circ} \mathrm{C}$.

\section{Purification of CSF}

CSF was purified from conditioned medium made from strain ROM186 (prototroph, $\Delta$ spo0K357::neo spoIVC::Tn917). The
spoIVC mutation was used to block spore formation completely. The spoOK allele is a deletion insertion (LeDeaux and Grossman 1995) and was used because preliminary results indicated that $s p o O K$ null mutations caused increased production of CSF, especially after entry into stationary phase (data not shown). The cells were grown in defined minimal medium with S7 salts (Vasantha and Freese 1980), trace metals, glucose (1\%), and glutamate $(0.1 \%)$, at $37^{\circ} \mathrm{C}$, essentially as described previously (Magnuson et al. 1994). Approximately $2 \mathrm{hr}$ after the onset of stationary phase, cells were removed by centrifugation and the supernatant was filter sterilized to produce cell-free conditioned medium. Nine hundred milliliters of this conditioned medium was adjusted to $\mathrm{pH} 2.0$ with TFA and applied to a 10-gram Sep-pak C-18 cartridge (Waters). Active CSF was recovered after step elution with $10 \%$ acetonitrile and $0.1 \%$ TFA $/ \mathrm{pH}$ 2.0). This material was applied to a SP column and eluted with a linear gradient of $\mathrm{NaCl}$ in $25 \mathrm{~mm}$ sodium acetate ( $\mathrm{pH} 4.0$ ). CSF eluted at $\sim 60 \mathrm{mM} \mathrm{NaCl}$, and active fractions were pooled and applied to a Vydac C-18 column for HPLC purification. Material was eluted using a linear gradient of acetonitrile $(\sim 0.2 \% / \mathrm{min})$ in $0.1 \%$ TFA. Active fractions were pooled and rerun under similar conditions. Finally, active fractions were pooled and rerun, this time eluting with a very shallow gradient of acetonitrile $(0.04 \% / \mathrm{min})$. Under these condition, CSF elutes at $<5 \%$ acetonitrile. After each step in the purification, active fractions were concentrated by roto-vap and/or Speedvac as necessary. Concentrated fractions were resuspended in buffers appropriate for the next step in the purification, and the $\mathrm{pH}$ was adjusted as necessary.

\section{Assay of CSF activity}

CSF activity was measured essentially as described for the 
ComX pheromone (Magnuson et al. 1994). Cells containing the srfA-lacZ 1974 fusion (JRL293) were grown for at least three doublings to an $\mathrm{OD}_{600}$ of $\sim 0.1$. Cells $(0.25 \mathrm{ml})$ were mixed with $0.25 \mathrm{ml}$ of the sample to be assayed, with $50 \mu \mathrm{g} / \mathrm{ml}$ of BSA to prevent nonspecific loss of activity (Magnuson et al. 1994), in a $2.2 \mathrm{-ml}$ plastic tube (Marsh Biomedical), incubated at $37^{\circ} \mathrm{C}$ for 70 min, and assayed for $\beta$-galactosidase specific activity. Samples to be assayed typically included conditioned medium, fresh medium, and column fractions diluted into fresh medium. Induced $\beta$-galactosidase specific activity is that induced by a given sample, above the background specific activity from cells incubated with fresh medium. The response to CSF was linear only over a small concentration range and assays were typically done on a series of twofold dilutions. The greatest dilution that gave an induced specific activity approximately twofold above background (fresh medium) was used to calculate the units of CSF per milliliter of conditioned medium. One unit of CSF activity is defined as the amount needed to induce expression of the srfA-lacZ $\Omega 1974$ fusion in strain JRL293 to an activity of one $\beta$-galactosidase specific activity unit above the background of untreated cells (fresh medium) in $70 \mathrm{~min}$.

\section{Acknowledgments}

We are grateful to Paul Matsudaira for his advice and use of his HPLC equipment, and to T. Baker, and members of our laboratory for comments and suggestions on the manuscript. J.M.S. was supported by a Howard Hughes predoctoral fellowship, and R.M. was supported in part by a National Institutes of Health (NIH) predoctoral training grant. A.D.G. was a Lucille P. Markey Scholar in Biomedical Sciences, and this work was supported in part by a grant from the Lucille P. Markey Charitable Trust and U.S. Public Health Service grants GM41934 and GM50895 to A.D.G. from the NIH.

The publication costs of this article were defrayed in part by payment of page charges. This article must therefore be hereby marked "advertisement" in accordance with 18 USC section 1734 solely to indicate this fact.

\section{References}

Albano, M., J. Hahn, and D. Dubnau. 1987. Expression of competence genes in Bacillus subtilis. I. Bacteriol. 169: 31103117.

Albano, M., R. Breitling, and D. Dubnau. 1989. Nucleotide sequence and genetic organization of the Bacillus subtilis comG operon. I. Bacteriol. 171: 5386-5404.

Alex, L.A. and M.I. Simon. 1994. Protein histidine kinases and signal transduction in prokaryotes and eukaryotes. Trends Genet. 10: 133-138.

Bourret, R.B., K.A. Borkovich, and M.I. Simon. 1991. Signal transduction pathways involving protein phosphorylation in prokaryotes. Anna. Rev. Biochem. 60: 401-441.

Burbulys, D., K.A. Trach, and J.A. Hoch. 1991. Initiation of sporulation in $B$. subtilis is controlled by a multicomponent phosphorelay. Cell 64: 545-552.

Chang, C., S.F. Kwok, A.B. Bleecker, and E.M. Meyerowitz. 1993. Arabidopsis ethylene-response gene ETR1: Similarity of product to two-component regulators. Science 262: 539544.

Clewell, D.B. 1993. Bacterial sex pheromone-induced plasmid transfer. Cell 73: 9-12.

Cornell, R.A. and D. Kimelman. 1994. Combinatorial signaling in development. BioEssays 16: 577-581.

Cox, G.B., D. Webb, J. Godovac-Zimmermann, and H. Rosen- berg. 1988. Arg-220 of the PstA protein is required for phosphate transport through the phosphate-specific transport system in Escherichia coli but not for alkaline phosphatase repression. J. Bacteriol. 170: 2283-2286.

D'Souza, C., M.M. Nakano, and P. Zuber. 1994. Identification of comS, a gene of the $\operatorname{srf} A$ operon that regulates the establishment of genetic competence in Bacillus subtilis. Proc. Natl. Acad. Sci. 91: 9397-9401.

Dubnau, D. 1991. Genetic competence in Bacillus subtilis. Microbiol. Rev. 55: 395-424.

-1993. Genetic exchange and homologous recombination. In Bacillus subtilis and other Gram-positive bacteria: Biochemistry, physiology, and molecular genetics (ed. A.L. Sonenshein, J.A. Hoch, and R. Losick), pp. 555-584. American Society for Microbiology, Washington, D.C.

Dubnau, D. and R. Davidoff-Abelson. 1971. Fate of transforming DNA following uptake by competent B. subtilis. I. Mol. Biol. 56: 209-221.

Dubnau, D., J. Hahn, L. Kong, M. Roggiani, and Y. Weinrauch. 1991. Genetic competence as a post-exponential global response. Sem. Dev. Biol. 2: 3-11.

Grossman, A.D. and R. Losick. 1988. Extracellular control of spore formation in Bacillus subtilis. Proc. Natl. Acad. Sci. 85: 4369-4373.

Grossman, A.D., T. Lewis, N. Levin, and R. DeVivo. 1992. Suppressors of a spoOA missense mutation and their effects on sporulation in Bacillus subtilis. Biochimie 74: 679-688.

Hahn, J. and D. Dubnau. 1991. Growth stage signal transduction and the requirements for $s r f A$ induction in development of competence. I. Bacteriol. 173: 7275-7282.

Hahn, J., L. Kong, and D. Dubnau. 1994. The regulation of competence transcription factor synthesis constitutes a critical control point in the regulation of competence in Bacillus subtilis. J. Bacteriol. 176: 5753-5761.

Hamoen, L.W., H. Eshuis, J. Jongbloed, G. Venema, and D. van Sinderen. 1995. A small gene, designated comS, located within the coding region of the fourth amino acid-activation domain of $s$ rf $A$, is required for competence development in Bacillus subtilis. Mol. Microbiol. 15: 55-63.

Higgins, C.F. 1992. ABC transporters: From microorganisms to man. Annu. Rev. Cell Biol. 8: 67-113.

Hoch, J.A. 1993. spo0 genes, the phosphorelay, and the initiation of sporulation. In Bacillus subtilis and other Gram-positive bacteria: Biochemistry, physiology, and molecular genetics (ed. A.L. Sonenshein, J.A. Hoch, and R. Losick), pp.747-755. American Society for Microbiology, Washington, D.C.

Hui, F.M. and D.A. Morrison. 1991. Genetic transformation in Streptococcus pheumoniae: Nucleotide sequence analysis shows $\operatorname{com} A$, a gene required for competence induction, to be a member of the bacterial ATP-dependent transport protein family. J. Bacteriol. 173: 372-381.

Ireton, K. and A.D. Grossman. 1992. Coupling between gene expression and DNA synthesis early during development in Bacillus subtilis. Proc. Natl. Acad. Sci. 89: 8808-8812.

-1994. A developmental checkpoint couples the initiation of sporulation to DNA replication in Bacillus subtilis. EMBO I. 13: 1566-1573.

Ireton, K., D.Z. Rudner, K.J. Siranosian, and A.D. Grossman. 1993. Intergration of multiple developmental signals in $\mathrm{Ba}$ cillus subtilis through the SpoOA transcription factor. Genes \& Dev. 7: 283-294.

Ireton, K., N.W. Gunther IV and A.D. Grossman. 1994. spoOI is required for normal chromosome segregation as well as the initiation of sporulation in Bacillus subtilis. I. Bacteriol. 176: $5320-5329$. 
Jaacks, K.J., J. Healy, R. Losick, and A.D. Grossman. 1989. Identification and characterization of genes controlled by the sporulation regulatory gene spoOH in Bacillus subtilis. I. Bacteriol. 171: 4121-4129.

Joenje, H., M. Gruber, and G. Venema. 1972. Stimulation of the development of competence by culture fluids in Bacillus subtilis transformation. Biochim. Biophys. Acta 262: 189199.

Koide, A. and J.A. Hoch. 1994. Identification of a second oligopeptide transport system in Bacillus subtilis and determination of its role in sporulation. Mol. Microbiol. 13:417426.

Kong, L. and D. Dubnau. 1994. Regulation of competence-specific gene expression by Mec-mediated protein-protein interaction in Bacillus subtilis. Proc. Natl. Acad. Sci. 91: 57935797.

LeDeaux, J.R. and A.D. Grossman. 1995. Isolation and characterization of kinC, a gene that encodes a sensor kinase homologous to the sporulation sensor kinases KinA and KinB in Bacillus subtilis. J. Bacteriol. 177: 166-175.

Magnuson, R., J. Solomon, and A.D. Grossman. 1994. Biochemical and genetic characterization of a competence pheromone from B. subtilis. Cell 77: 207-216.

Miller, J. 1972. Experiments in molecular genetics. Cold Spring Harbor Laboratory, Cold Spring Harbor, New York.

Msadek, T., F. Kunst, and G. Rapoport. 1994. MecB of Bacillus subtilis, a member of the ClpC ATPase family, is a pleiotropic regulator controlling competence gene expression and growth at high temperature. Proc. Natl. Acad. Sci. 91: 57885792.

Nakano, M.M. and P. Zuber. 1989. Cloning and characterization of $s r f B$, a regulatory gene involved in surfactin production and competence in Bacillus subtilis. I. Bacteriol. 171: $5347-5353$.

- 1991. The primary role of ComA in establishment of the competent state in Bacillus subtilis is to activate expression of srfA. J. Bacteriol. 173: 7269-7274.

Nakano, M.M., M.A. Marahiel, and P. Zuber. 1988. Identification of a genetic locus required for biosyntheses of the lipopeptide antibiotic surfactin in Bacillus subtilis. I. Bacteriol. 170: 5662-5668.

Nakano M.M., R. Magnuson, A. Meyers, J. Curry, A.D. Grossman and P. Zuber. 1991a. $\operatorname{srf} A$ is an operon required for surfactin production, competence development, and efficient sporulation in Bacillus subtilis. J. Bacteriol. 173: $1770-1778$.

Nakano, M.M., L. Xia, and P. Zuber. 1991b. Transcription initiation region of the srfA operon, which is controlled by the ComP-ComA signal transduction system in Bacillus subtilis. I. Bacteriol. 173: 5487-5493.

Ota, I.M. and A. Varshavsky. 1993. A yeast protein similar to bacterial two-component regulators. Science 262: 566-569.

Parkinson, J.S. and E.C. Kofoid. 1992. Communication modules in bacterial signaling proteins. Annu. Rev. Genet. 26: 71112.

Pearce, B.J., A.M. Naughton, and H.R. Masure. 1994. Peptide permeases modulate transformation in Streptococcus pneumoniae. Mol. Microbiol. 12: 881-892.

Perego, M., G.B. Spiegelman, and J.A. Hoch. 1988. Structure of the gene for the transition state regulator, $a b r B$ : Regulator synthesis is controlled by the spoOA sporulation gene in $\mathrm{Ba}$ cillus subtilis. Mol. Microbiol. 2: 689-699.

Perego, M., C.F. Higgins, S.R. Pearce, M.P. Gallagher, and J.A. Hoch. 1991. The oligopeptide transport system of Bacillus subtilis plays a role in the initiation of sporulation. Mol. Microbiol. 5: 173-185.
Piggot, P.J. and J.G. Coote. 1976. Genetic aspects of bacterial endospore formation. Bacteriol. Rev. 40: 908-962 .

Roggiani, M. and D. Dubnau. 1993. ComA, a phosphorylated response regulator protein of Bacillus subtilis, binds to the promoter region of srfA. J. Bacteriol. 175: 3182-3187.

Rudner, D.Z., J.R. LeDeaux, K. Ireton, and A.D. Grossman. 1991. The spoOK locus of Bacillus subtilis is homologous to the oligopeptide permease locus and is required for sporulation and competence. I. Bacteriol. 173: 1388-1398.

Ruhfel, R.E., D.A. Manias, and G.M. Dunny. 1993. Cloning and characterization of a region of the Enterococcus faecalis conjugative plasmid, pCF10, encoding a sex pheromone-binding function. J. Bacteriol. 175: 5253-5259.

Sadaie, Y. and T. Kada. 1983. Formation of competent Bacillus subtilis cells. J. Bacteriol. 153: 813-821.

Shapiro, L., D. Kaiser, and R. Losick. 1993. Development and behavior in bacteria. Cell 73: 835-836.

Siranosian, K.J. and A.D. Grossman. 1994. Activation of spo0A transcription by sigma-H is necessary for sporulation but not for competence in Bacillus subtilis. J. Bacteriol. 176: 38123815.

Smith, H.O. and D.B. Danner. 1981. Genetic transformation. Annu. Rev. Biochem. 50: 41-68.

Stewart, G.J. 1989. The mechanism of natural transformation. In Gene transfer in the environment (ed. S.B. Levy and R.V. Miller), pp. 139-164. McGraw-Hill, New York.

Strauch, M. and J.A. Hoch. 1993. Transition-state regulators: Sentinels of Bacillus subtilis post-exponential gene expression. Mol. Microbiol. 7: 337-342.

Strauch, M.A., V. Webb, G. Spiegelman, and J.A. Hoch. 1990. The Spo0A protein of Bacillus subtilis is a repressor of the $a b r B$ gene. Proc. Natl. Acad. Sci. 87: 1801-1805.

Tanimoto, K., F.Y. An, and D.B. Clewell. 1993. Characterization of the traC determinant of the Entercoccus faecalis hemolysin-bacteriocin plasmid pADl: Binding of sex pheromone. J. Bacteriol. 175: 5260-5264.

Tomasz, A. and R.D. Hotchkiss. 1964. Regulation of the transformability of pneumococcal cultures by macromolecular cell products. Proc. Natl. Acad. Sci. 51: 480-487.

Tomasz, A. and J.L. Mosser. 1966. On the nature of the pneumococcal activator substance. Proc. Natl. Acad. Sci. 55: 5866.

Tynkkynen, S., G. Buist, E. Kunji, J. Kok, B. Poolman, G. Venema, and A. Haandrikman. 1993. Genetic and biochemical characterization of the oligopeptide transport system of Lactococcus lactis. I. Bacteriol. 175: 7523-7532.

Valdivia, R.H., L. Wang, and S.C. Winans. 1991. Characterization of a putative periplasmic transport system for octopine accumulation encoded by Agrobacterium tumefaciens. I. Bacteriol. 173: 6398-6405.

van Sinderen, D. and G. Venema. 1994. comK acts as an autoregulatory control switch in the signal transduction route to competence in Bacillus subtilis. I. Bacteriol. 176: 57625770 .

van Sinderen, D., S. Withoff, H. Boels, and G. Venema. 1990. Isolation and characterization of $c o m L$, a transcription unit involved in competence development of Bacillus subtilis. Mol. \& Gen. Genet. 224: 396-404.

van Sinderen, D., A. ten Berge, B.J. Hayema, L. Hamoen, and G. Venema. 1994. Molecular cloning and sequence of $\operatorname{comK}$, a gene required for genetic competence in Bacillus subtilis. Mol. Microbiol. 11: 695-703.

Vasantha, N. and E. Freese. 1979. The role of manganese in growth and sporulation of Bacillus subtilis. J. Gen. Microbiol. 112: 329-336.

. 1980. Enzyme changes during Bacillus subtilis sporula- 
tion caused by deprivation of guanine nucleotides. $I$. Bacteriol. 144: 1119-1125.

Waldburger, C., D. Gonzalez, and G.H. Chambliss. 1993. Characterization of a new sporulation factor in Bacillus subtilis. J. Bacteriol. 175: 6321-6327.

Wanner, B.L. 1993. Gene regulation by phosphate in enteric bacteria. J. Cell. Biochem. 51: 47-54.

Weinrauch, Y., R. Penchev, E. Dubnau, I. Smith, and D. Dubnau. 1990. A Bacillus subtilis regulatory gene product for genetic competence and sporulation resembles sensor protein members of the bacterial two-component signal-transduction systems. Genes \& Dev. 4: 860-872.

Youngman, P., H. Poth, B. Green, K. York, G. Olmedo, and K. Smith. 1989. Methods for genetic manipulation, cloning, and functional analysis of sporulation genes in Bacillus subtilis. In Regulation of procaryotic development (ed. I. Smith, R. Slepecky and P. Setlow), pp. 65-87. American Society for Microbiology, Washington, D.C.

Zanker, H., J. von Lintig, and J. Schroeder. 1992. Opine transport genes in the octopine $(o c c)$ and the nopaline (noc) catabolic regions in Ti plasmids of Agrobacterium tumefaciens. I. Bacteriol. 174: 841-849. 


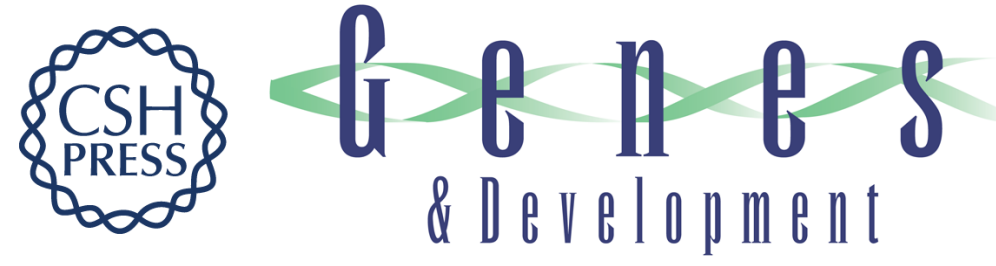

\section{Convergent sensing pathways mediate response to two extracellular competence factors in Bacillus subtilis.}

J M Solomon, R Magnuson, A Srivastava, et al.

Genes Dev. 1995, 9:

Access the most recent version at doi:10.1101/gad.9.5.547

References This article cites 65 articles, 40 of which can be accessed free at:

http://genesdev.cshlp.org/content/9/5/547.full.html\#ref-list-1

License

Email Alerting

Service

Receive free email alerts when new articles cite this article - sign up in the box at the top right corner of the article or click here.

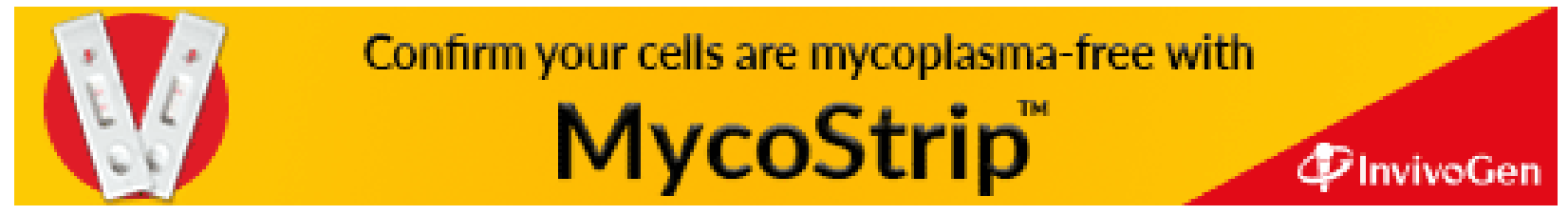

